\title{
Complex Tic
}

National Cancer Institute

\section{Source}

National Cancer Institute. Complex Tic. NCI Thesaurus. Code C116762.

A tic that involves multiple muscles or muscle groups, or words or sentences. 